\title{
EVALUATION OF THERAPEUTIC SUBSTANCES EMPLOYED FOR THE RELIEF OF BRONCHOSPASM. V. ADRENERGIC AGENTS ${ }^{1}$
}

\author{
By ELLIOTT BRESNICK,2 JOHN F. BEAKEY,3 LEON LEVINSON,4 \\ AND MAURICE S. SEGALs
}

\author{
(From the Department of Inhalational Therapy, Boston City Hospital, and the Department of \\ Medicine, Tufts College Medical School, Boston)
}

(Received for publication March 31, 1949)

Many laboratory techniques have been employed in the study of sympathomimetic amines, particularly in an attempt to correlate chemical structure with pharmacological activity (1-7). In Table I are shown the structural formulae of the preparations dealt with in this report.

The technique of protection studies in asthmatic human subjects appears to offer an additional method of investigating and evaluating these and other substances in the ultimate test object, man. The technique essentially consists of the measurement of the protection afforded by any substance against the dyspnea and bronchospasm induced by repeated administrations of histamine, methacholine, or allergens, as measured, in part at least, by changes in vital capacity.

\section{METHODS}

The methods we have employed and their historical development have been extensively presented elsewhere $(8,9)$.

In the experiments reported at this time, the bronchospastic agents used were histamine diphosphate ${ }^{b}$ and methacholine chloride, ${ }^{7}$ employed intravenously or as aerosols. The protecting ability of the therapeutic agent under examination was determined by serial observations of the reduction in vital capacity produced by repeated administration of a constant dose (predetermined as capable of producing a consistent reduction in vital capacity

\footnotetext{
1 This study was supported by a grant from the United States Public Health Service.

2 Out-Patient Physician, Boston City Hospital; Former Charlton Research Fellow and now Assistant in Medicine, Tufts College Medical School.

${ }^{3}$ Research Fellow in Medicine, Tufts College Medical School.

4 Assistant in Medicine, Tufts College Medical School.

5 Director, Department of Inhalational Therapy, Boston City Hospital; Assistant Professor of Medicine, Tufts College Medical School.

- Kindly supplied by Abbott Laboratories, Inc., Chicago, Illinois.

' Kindly supplied by Merck and Company, Rahway, New Jersey.
}

of at least 25 per cent) of histamine or methacholine at varying intervals after the protecting agent was administered. The degree of protection may be described in terms of the following equation:

$$
P=\frac{C-E}{C} \times 100
$$

where $P$ is the degree of protection in per cent, $C$ the control drop in vital capacity produced by administration of the bronchospastic substance (before the protecting drug is given), and $E$ the drop similarly produced at any time after the protecting agent has been administered. These percentage values may then be massed into averages derived from several experiments on different asthmatic subjects. Determination of such averages is necessary, for we have repeatedly encountered single protection studies, or even repeated studies in the same individual, which were at variance with the average of results obtained by employing the same drugs in many experiments carried out on many individuals.

\section{RESULTS}

1. Epinephrine hydrochloride. Epinephrine hydrochloride $1: 1000,0.5 \mathrm{cc}$. subcutaneously, cause the usual side-reactions of throbbing in the chest and head, uneasiness, tremor, etc. Protection was striking, however, in that this dose afforded 100 per cent "immediate" (five to ten minutes after injection) protection against intravenous histamine. This decreased gradually reaching a level of 40 per cent after 143 minutes (Figure 1). This 40 per cent level has previously (9) been proposed as the minimum at which protection may be considered significant, in view of the errors inherent in any technique of clinical assay. Against the bronchospastic effects of methacholine, epinephrine hydrochloride $1: 1000,0.5 \mathrm{cc}$. subcutaneously, provided 90 per cent immediate protection and maintained a significant level, over 40 per cent, for 83 minutes. These results are presented in tabular form in Table II.

Subcutaneously administered epinephrine was also assayed against the bronchospastic effect of aerosols of histamine and methacholine and dis- 
TABLE I

Structural relationships of the sympathomimetic agents studied. (Modified from Gunn [3])

\begin{tabular}{|c|c|c|c|c|c|c|}
\hline NEOSYNEPHRIN & $H$ & $\mathrm{OH}$ & $\mathrm{H}$ & $\mathrm{OH}$ & H & $\mathrm{CH}_{3}$ \\
\hline EPINEPHRINE & $\mathrm{OH}$ & $\mathrm{OH}$ & $H$ & $\mathrm{OH}$ & H & $\mathrm{CH}_{3}$ \\
\hline VAPONEFRIN & $\mathrm{OH}$ & $\mathrm{OH}$ & $\mathrm{H}$. & $\mathrm{OH}$ & $H$ & $\mathrm{CH}_{3}$ \\
\hline ISUPREL & $\mathrm{OH}$ & $\mathrm{OH}$ & $\mathrm{H}$ & $\mathrm{OH}$ & $H$ & \\
\hline EPHEDRINE & $\mathrm{H}$ & H & $\mathrm{H}$ & $\mathrm{OH}$ & $\mathrm{CH}_{3}$ & $\mathrm{CH}_{3}$ \\
\hline ORTHOXINE & H & $H$ & $\mathrm{OCH}_{3}$ & $H$ & $\mathrm{CH}_{3}$ & $\mathrm{CH}_{3}$ \\
\hline
\end{tabular}

Vaponefrin is a specially prepared racemic epinephrine.

played somewhat less, though still very effective protecting ability. Against histamine it showed 70 per cent immediate protection, which rose to a peak of 86 per cent at 40 minutes, and maintained a level greater than 40 per cent for 127 minutes. Less protection against methacholine was again observed; there was an immediate level of 40 per cent, rising to a peak of 51 per cent at 38 minutes, and remaining at a significant level for 72 minutes.

The $1: 100$ dilution of epinephrine hydrochloride (10) was dispensed in a glycerine-water solution, as were all other agents employed as aerosolized mists. Deep inhalations at ten-second intervals were administered with a standard Vaponefrin hand-bulb nebulizer until six were completed. Against intravenous histamine 75 per cent immediate protection was observed. The significant level of 40 per cent lasted for 28 minutes. Against intravenous methacholine there was 56 per cent immediate protection and an 18 minute duration of the 40 per cent level (Figure 2).

The protective capacity of epinephrine aerosol appeared slightly greater when assayed against nebulized bronchospastic agents. There was 89 per cent immediate protection and 36-minute duration of the 40 per cent level against histamine;
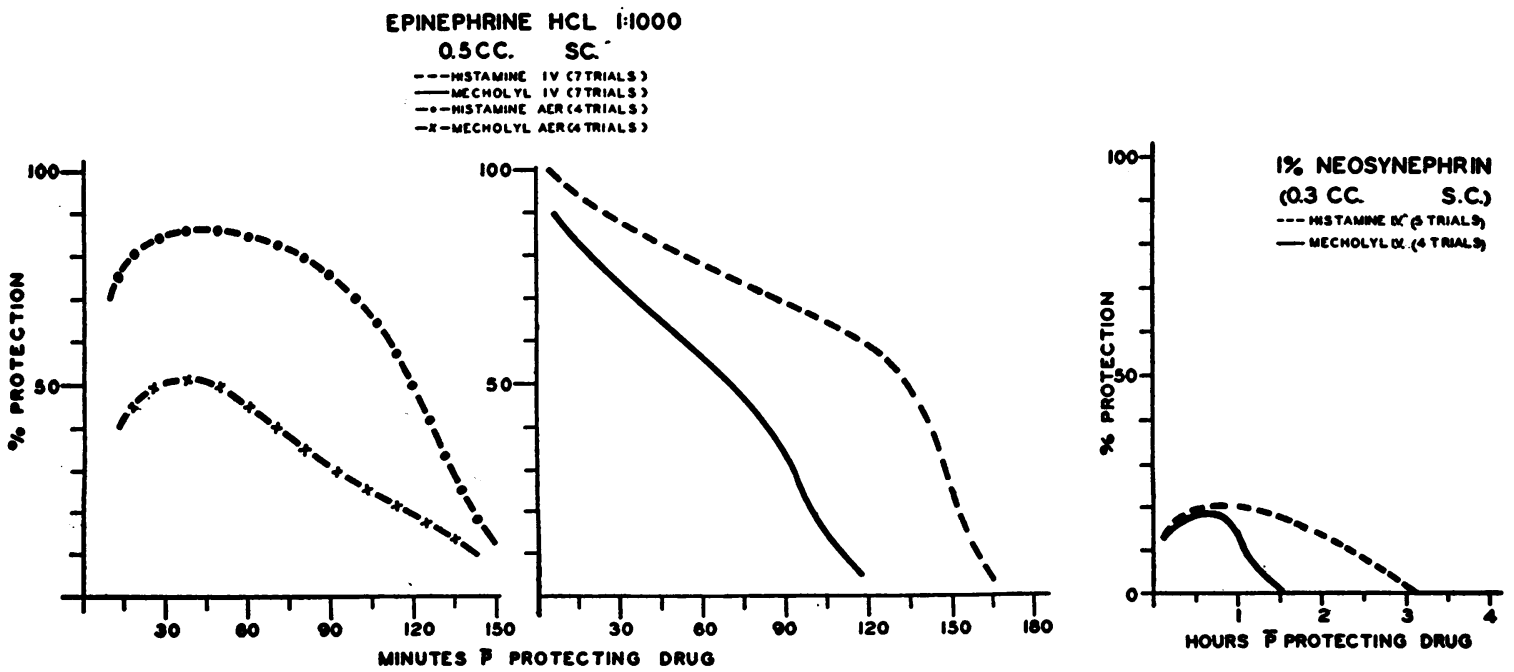

Fig. 1. The Protection Afforded Against Histamine and Methacholine (Referred to Above as Mecholyl) by 0.5 cc. of Epinephrine Hydrochloride $1: 1000$, and 0.3 cc. of 1 Per Cent Neosynephrin Administered Subcutaneously 
TABLE II

Summary of the pertinent data obtained with the phenylethylamines when tested against the bronchospastic effects of histamine and methacholine (referred to below as mecholyl)

BRONCHOCONSTRICTING AGENT

\begin{tabular}{|c|c|c|c|c|c|c|c|c|}
\hline \multirow{2}{*}{$\begin{array}{c}\text { PROTECTING } \\
\text { DRUG }\end{array}$} & \multicolumn{2}{|c|}{ HISTAMINE IV } & \multicolumn{2}{|c|}{ MECHOLYL I.V. } & \multicolumn{2}{|c|}{ HISTAMINE AER. } & \multicolumn{2}{|c|}{ MECHOLYL AER. } \\
\hline & $\begin{array}{l}\text { IMMEEDAATE } \\
\text { PROTECTION } \\
\text { (\%) }\end{array}$ & \begin{tabular}{|c|} 
DURATION OF \\
SIGNIFICANT (4OX) \\
PROTECTION \\
(MINUTES)
\end{tabular} & $\begin{array}{l}\text { IMOMEDIATE } \\
\text { PROTECTION } \\
\text { (\%) }\end{array}$ & $\begin{array}{l}\text { DURATION OF } \\
\text { SIGNIFICANT (40X) } \\
\text { PROTECTION } \\
\text { (MNUTES) }\end{array}$ & $\begin{array}{l}\text { IMMEDIATE } \\
\text { PROTECTION } \\
\text { (\%) }\end{array}$ & \begin{tabular}{|} 
DURATION OF \\
SIGNIFICANT (40\%) \\
PROTECTION \\
(MINUTES)
\end{tabular} & $\begin{array}{c}\text { MMMEDIATE } \\
\text { PROTECTION } \\
\text { (\%) }\end{array}$ & $\begin{array}{l}\text { DURATION OF } \\
\text { SIGNIFICANT (40X) } \\
\text { PROTECTION } \\
\text { (MINUTES) }\end{array}$ \\
\hline $\begin{array}{l}\text { EPINEPHRINE } \\
1: 1000,0.5 \mathrm{CC} ., \mathrm{SC}\end{array}$ & 100 & 143 & 90 & 83 & 70 & 127 & 40 & 72 \\
\hline $\begin{array}{c}\text { EPINEPHRINE } \\
\text { I:100 AER. }\end{array}$ & 75 & 28 & 56 & 18 & 89 & 36 & 66 & 17 \\
\hline $\begin{array}{l}\text { VAPONEFRIN } \\
2.25 \% \text { AER. }\end{array}$ & 93 & 27 & 74 & 18 & 90 & 53 & 87 & 40 \\
\hline $\begin{array}{l}\text { NEOSYNEPHRIN } \\
1: 100, \quad 0.3 C C ., \text { S.C. }\end{array}$ & 13 & 0 & 13 & 0 & & & & \\
\hline $\begin{array}{l}\text { NEOSYNEPHRIN } \\
\text { l:100 AER. }\end{array}$ & 52 & 16 & 32 & 0 & & & & \\
\hline $\begin{array}{l}\text { ISUPREL } \\
\text { I:100 AER. }\end{array}$ & 98 & 62 & 91 & 81 & & & & \\
\hline $\begin{array}{l}\text { ISUPREL } \\
1: 200 \text { AER. }\end{array}$ & 70 & 22 & 69 & 42 & 84 & 21 & 65 & 25 \\
\hline $\begin{array}{c}\text { ISUPREL } \\
\text { 1:5000, Q.5CC., S.C. }\end{array}$ & 100 & 30 & 56 & 18 & & & & \\
\hline
\end{tabular}

and 66 per cent immediate and 17-minute duration of the 40 per cent level against methacholine. These data are not, however, significantly different from those obtained with the intravenous bronchospastics.

2. Vaponefrin. $^{8}$ This is a 2.25 per cent solution of a specially prepared synthetic racemic epinephrine. Richards, Barach and Cromwell (11) considered it preferable to the official $1: 100$ solution of epinephrine hydrochloride, which is the levo-rotatory isomer. We have compared these aerosols elsewhere (12).

Using histamine intravenously we found that six deep inhalations of Vaponefrin aerosol provided 93 per cent immediate protection and significant protection (over 40 per cent) lasting 27 minutes. Against intravenous methacholine we obtained an immediate level of 74 per cent and a duration of a significant level of 18 minutes. Employing the bronchospastics by nebulization resulted in no greatly significant difference in intensity of action, 90 per cent against histamine and 87 per cent against methacholine. However, the 40 per cent level was maintained definitely longer, 53 minutes with histamine and 40 minutes with methacholine (Figure 2). The explanation for this discrepancy is obscure; it may simply be due to inadequate sampling.

8 Kindly supplied by the Vaponefrin Co., Upper Darby, Pennsylvania.
3. Neosynephrin. As may be seen from Table I, this drug differs from epinephrine only in the absence of the para-hydroxyl group on the aromatic portion of the molecule. The compounds resulting from removal of one or both hydroxyl groups are more stable but have greatly decreased inhibitory effects. Various investigators $(11,13$ 15) have found neosynephrin of little value as a bronchodilator although it may be an efficient bronchovasoconstrictor $(14,15)$.

Utilizing the $1: 100$ solution of neosynephrin, we have studied the protecting effect of the drug administered by nebulizer and by hypodermic injection. Our studies were limited to intravenous use of the bronchospastic agents. Figure 1 portrays the ineffectiveness of $0.3 \mathrm{cc}$. subcutaneously, the level of protection never exceeding 20 per cent. Neosynephrin aerosol, 1:100, in the usual dose of six deep inhalations, proved somewhat more effective (Figure 2), displaying against histamine 52 per cent immediate protection which dropped below 40 per cent within 16 minutes. Against methacholine no significant protective levels were attained, 32 per cent being the highest observed.

4. Isuprel. ${ }^{9}$ This sympathomimetic amine, 1-(3,4-dihydroxyphenyl)-2-isopropylaminoethanol differs from epinephrine only in the alkyl group

9 Kindly supplied by Winthrop-Stearns, Inc., New York, New York. 

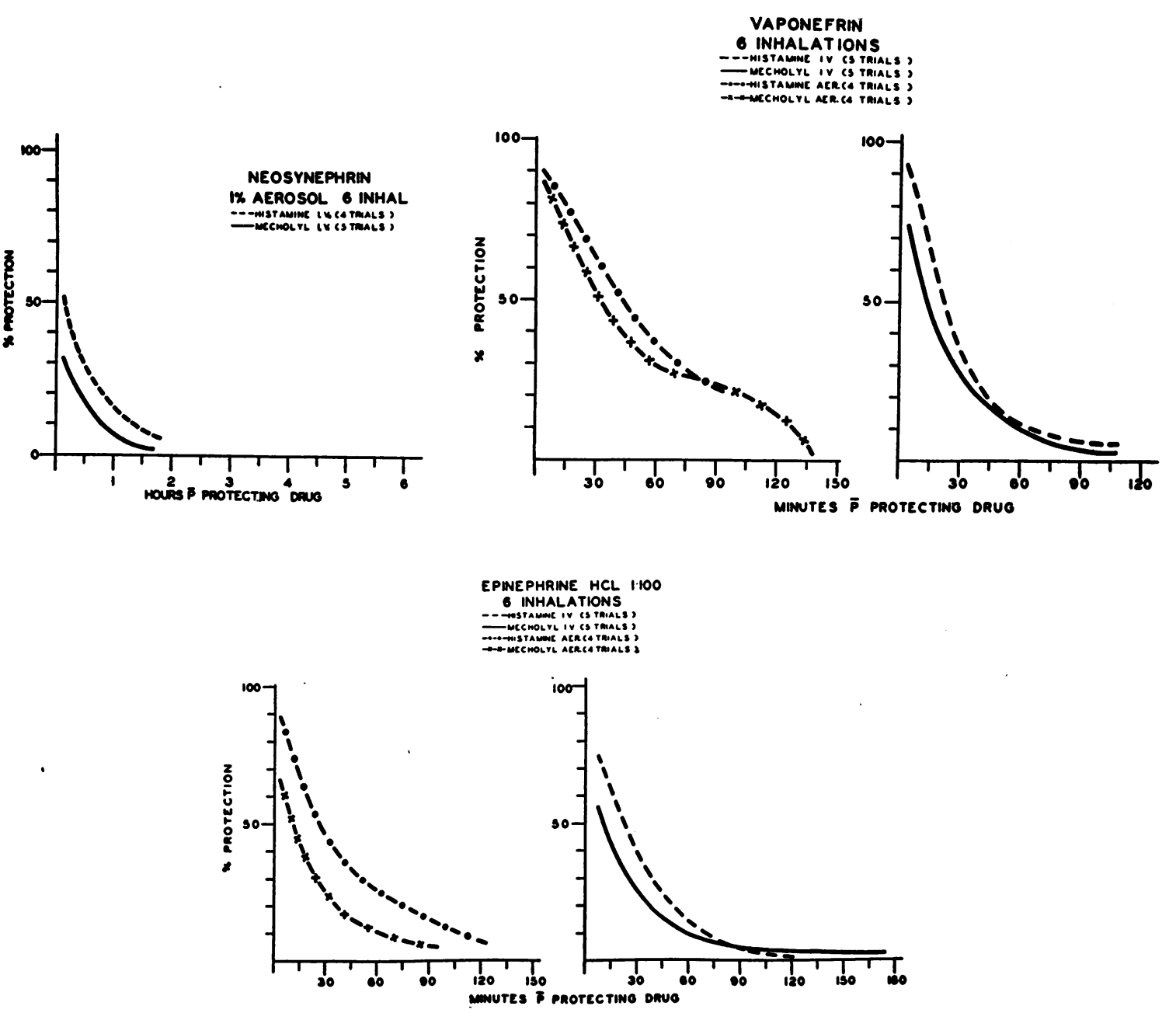

Fig. 2. The Protection Noted Against Histamine and Methacholine (Referred to Above as Mecholyl) by Nebulized Solutions of Epinepihrine Hydrochloride $(1: 100)$, Vaponefrin $(2.25$ Per Cent) aNd Neosynephrin (1 Per Cent)

attached to the nitrogen atom (Table I). It has been demonstrated that substitution on the amino nitrogen of branched alkyl groups, particularly isopropyl (as in Isuprel) and terbutyl, produces compounds with enhanced sympathin I-mimetic properties $(4-7,16)$. The specific structure of the substituted alkyl group is also important in influencing the inhibitory potency of such compounds.

The clinical efficacy of Isuprel has been previously reviewed by Segal and Beakey $(17,18)$, who introduced its use in this country. Cohen and Van Bergen (19) have found Isuprel a most effective antagonist of methacholine-induced bronchospasm in animals and of spontaneous asthma in man.
We have employed a $1: 50,000$ dilution of Isuprel intravenously in a few subjects with variable results. Occasionally the most dramatic possible complete relief of clinical asthma has been noted, while a dose of $0.25 \mathrm{cc}$. $(0.005 \mathrm{mgm}$.) was still being administered. The effect persisted for a matter of hours. In other instances relief was only partial and transient after intravenous administration of $0.25 \mathrm{cc}$. $(0.005 \mathrm{mgm}$.) to $0.5 \mathrm{cc}$. $(0.01$ mgm.), even in repeated doses. The 0.25 cc. dose caused a uniform increase of $20-30$ beats per minute in the heart rate. All patients experienced unpleasant, although not alarming, palpitations. The $0.5 \mathrm{cc}$. dose, on the other hand, accelerated the pulse by 50 beats per minute and caused uneasiness and alarming palpitations. The 
effect on blood pressure was minimal. The dose of $0.005 \mathrm{mgm}$. appeared to cause a small increase in systolic pressure (approximately $10 \mathrm{~mm}$. of mercury), probably due mainly to the increased rate. There appeared to be, in general, a tendency toward a slight fall in the diastolic level. The larger dose, $0.01 \mathrm{mgm}$. ( $0.5 \mathrm{cc}$.), caused a transient drop in systolic and diastolic levels simultaneous with the greatest increase in heart rate. We performed several protection studies using this very dilute solution of Isuprel intravenously. Doses of $0.25 \mathrm{cc}$. $(0.005 \mathrm{mgm}$.) and $0.5 \mathrm{cc}$. $(0.01 \mathrm{mgm}$.) failed to demonstrate any protective ability against histamine or methacholine for long enough periods to be measured by the method employed.

Isuprel $1: 100$, the dilution commonly employed
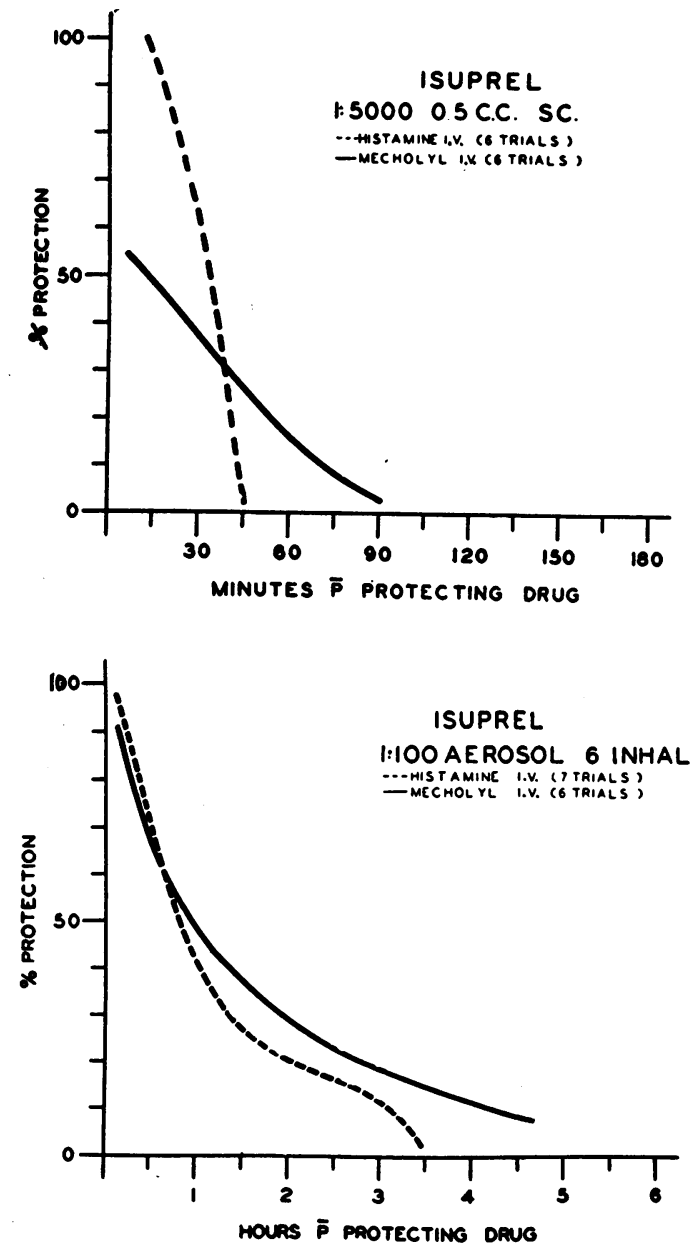

with epinephrine, provided essentially complete immediate protection against intravenous histamine and methacholine (98 and 91 per cent respectively). Not only did it maintain a significant (40 per cent) protection against histamine for 62 minutes, but it also afforded a surprising 81-minute duration against methacholine (Figure 3). However, this dilution of Isuprel frequently caused unpleasant epinephrine-like side-effects.

Isuprel $1: 200$ is the dilution in common use for nebulization. It is, of course, one-half as concentrated as the usual epinephrine solution and equivalent to approximately one-third the concentration of levo-epinephrine in Vaponefrin. This dilution of Isuprel displayed (Figure 3) 70 per cent immediate protection against intravenous histamine with a duration of 22 minutes for
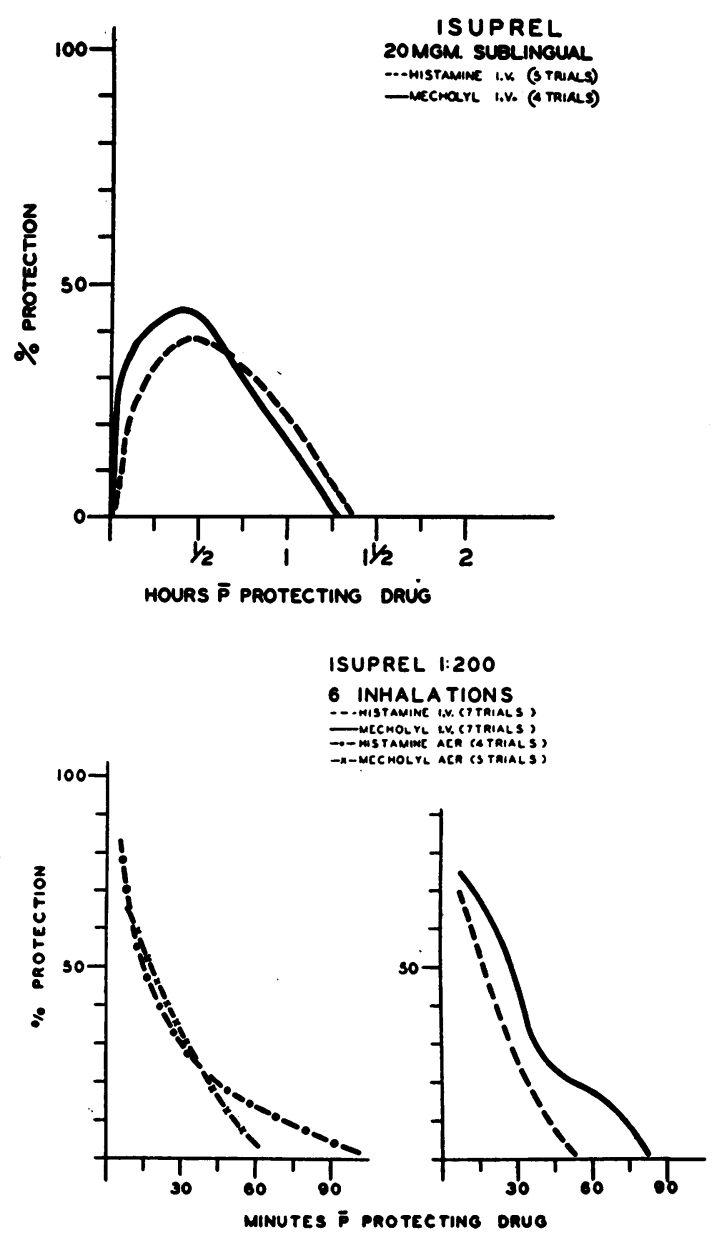

Fig. 3. The Protective Capacity of Isuprel Administered by Varied Routes and in Varied Amounts Against Histamine and Methacholine (Referred to Above as Mecholyl) 
significant levels. Against intravenous methacholine, there was a 69 per cent immediate level and significant levels persisted for 42 minutes. As may be seen in Table II, the data were, with one exception, essentially equivalent when the bronchospastics were employed in the form of aerosols. An immediate level of 84 per cent and a 21-minute duration of significant protection were found against histamine; and 65 per cent with 25 minutes were the comparable values for methacholine. The only discrepancy appears in the duration of levels over 40 per cent against methacholine administered intravenously and as an aerosol. This, again, may be due to inadequate sampling and the consequent chance inclusion of patients with extreme differences in responsiveness to Isuprel.

An average dose of the 1:5000 dilution of Isuprel for subcutaneous injection is $0.5 \mathrm{cc}$. This dose was assayed against intravenous histamine and methacholine (Figure 3). We obtained complete (100 per cent) immediate protection against histamine and a continuation of significant levels for 30 minutes. Less anticholinergic effect was noted with this preparation, for the initial intensity was only 56 per cent, and it dropped to 40 per cent in 18 minutes.

Sublingual tablets of Isuprel, although they have been moderately effective clinically in occasional patients, have not proved to be an adequate substitute for a nebulizer in most cases. We have performed protection studies with these tablets in doses of $20 \mathrm{mgm}$. (two tablets) against histamine and methacholine administered intravenously. Against histamine, significant levels of protection were not attained, and a peak of 38 per cent was reached in 27 minutes. Against methacholine the results were very similar although the 40 per cent level was reached in 12 minutes after the tablets dissolved under the tongue. (Time for dissolution was usually two to three minutes.) The total duration of levels over 40 per cent was 23 minutes. However, the peak level, attained 24 minutes after dissolution of the tablets, was only 44 per cent. These data are presented graphically in Figure 3.

5. Ephedrine. From Table I it may be seen that ephedrine is lacking in the hydroxyl groups on the benzene ring, and possesses an additional methyl group attached to the alpha-carbon atom.
Clinically it has longer, less intense action than epinephrine; it is active orally.

In our studies, employing the usual oral dose of $25 \mathrm{mgm}$. (administered several hours after the subject's last meal), there was a delay of $81 \mathrm{~min}$ utes before a protection level of 40 per cent was reached against histamine (Figure 4). A peak level of 57 per cent was attained at 120 minutes. Significant levels of 40 per cent or over were maintained for 108 minutes, or until slightly over three hours after the drug was taken. Against methacholine, no significant levels of protection were reached. The peak level was only 32 per cent, occurring 60 minutes after ingestion of the therapeutic agent.
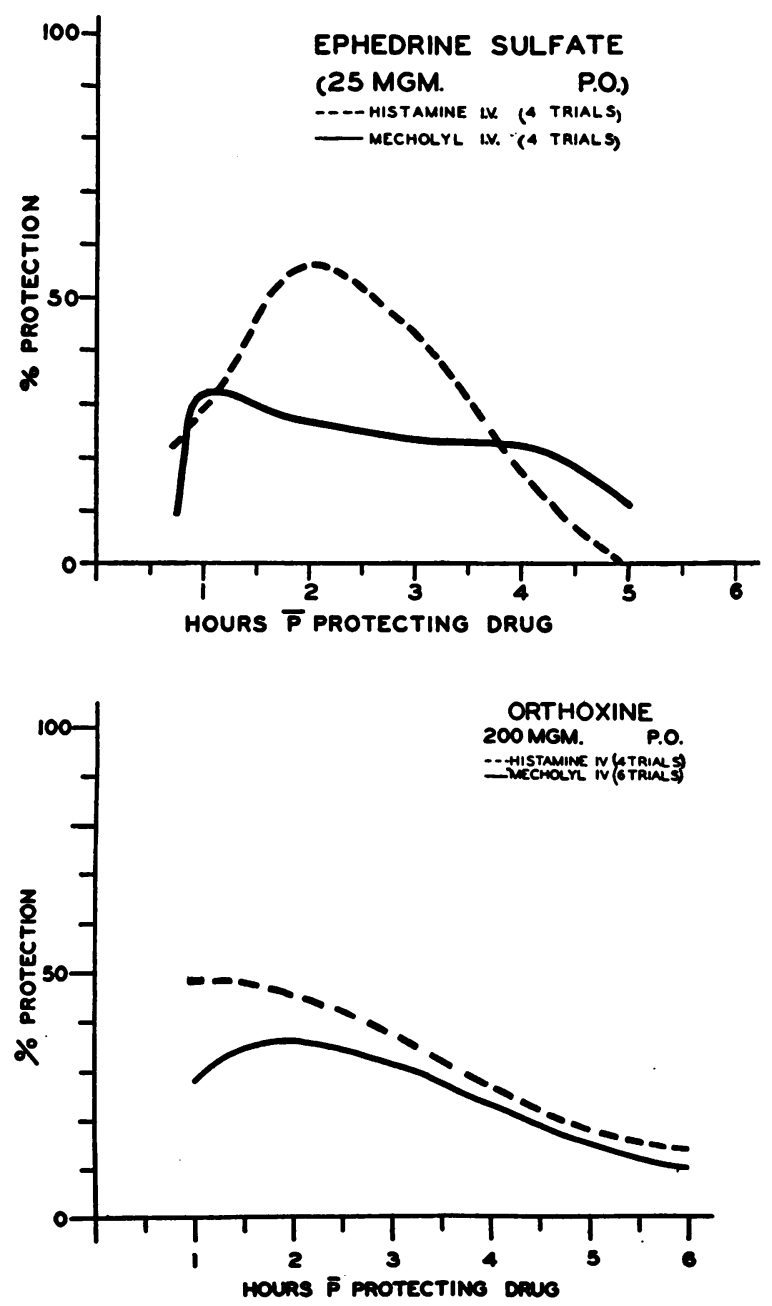

Fig. 4. The Protecting Ability of Orally Administered Ephedrine Sulfate (25 mgm.) and Orthoxine (200 mgm.) Against Histamine and Methacholine (Referred to Above as Mecholyl) 
6. Orthoxine. ${ }^{10}$ This synthetic amine differs from ephedrine in the absence of the beta-hydroxyl group and the presence of a methoxy radical in the ortho position.

We have made a clinical trial in approximately 20 patients with a dose of $100-200 \mathrm{mgm}$. three to four times daily: In general it proved to be of little benefit in preventing severe asthmatic attacks, although one patient obtained moderate relief and one noted marked improvement. Sideeffects were observed by many patients and varied among anorexia, nausea, light-headedness, dizziness and drowsiness. Only one patient complained of the ephedrine-like effect of insomnia. The syrup of orthoxine has been tolerated fairly well and appears to give clinical relief from troublesome cough in some patients.

In protection studies against intravenous histamine, orthoxine, in a dose of $200 \mathrm{mgm}$. orally, was apparently rapidly absorbed, for it displayed 49 per cent protection at 57 minutes. In addition, this proved to be the peak level attained inasmuch as the protective capacity dropped very gradually to 40 per cent at 165 minutes after ingestion of the drug. The total measured duration of significant protection was 108 minutes. Against methacholine, a 40 per cent level was never reached. The peak attained was 38 per cent at 120 minutes. These figures for orthoxine, graphically presented in Figure 4, obviously are very closely similar to those for ephedrine.

\section{SUMMARY AND CONCLUSIONS}

1. Five well-known sympathomimetic amines and one new one have been studied with respect to their protective capacity against the bronchospastic effects of histamine and methacholine in sensitive asthmatic patients.

2. No consistent difference in results was observed whether the bronchospastic agents were administered intravenously or as aerosols.

3. Epinephrine hydrochloride $1: 1000,0.5 \mathrm{cc}$. subcutaneously, protected as well as or better than the other agents tested and afforded greater duration of significant protection. However, its cardiovascular and central nervous stimulating sidereactions proved disagreeable.

\footnotetext{
10 Kindly supplied by The Upjohn Co., Kalamazoo, Michigan.
}

4. Isuprel 1:100 aerosol (double the usual strength), six inhalations, was comparable to the subcutaneously administered epinephrine, particularly in anticholinergic effect, although it protected less than half as long against histamine. This, too, caused undesirable side-effects.

5. Of the three most commonly employed solutions for nebulization, Vaponefrin, 2.25 per cent, appeared to have a slightly greater antihistaminic protecting ability than Isuprel $1: 200$ and epinephrine $1: 100$. The latter two were of approximately equal efficacy as antihistaminics. Isuprel 1:200 demonstrates greater anticholinergic protecting ability than either of the other two preparations.

6. Neosynephrin was quite ineffective when injected parenterally and of only slight value by the inhalatory route.

7. Sublingually administered Isuprel, in a dose of $20 \mathrm{mgm}$., proved to have little protective capacity against the bronchospastic effects of histamine and methacholine. It was occasionally of moderate value clinically when administered by this route.

8. Isuprel $1: 5000,0.5 \mathrm{cc}$. subcutaneously, displayed excellent though brief protecting ability against the bronchospastic effects of histamine and considerably less effectiveness against methacholine.

9. Isuprel $1: 50,000$ could not, because of cardiovascular side-effects, be injected intravenously in doses sufficient to effect measurable protection. Doses of $0.25 \mathrm{cc}$. and $0.5 \mathrm{cc}$. (0.005 to $0.01 \mathrm{mgm}$.) occasionally proved dramatically effective in alleviating clinical asthma, although it usually was less effective and quite transiently so.

10. A new sympathomimetic amine, orthomethoxy-beta-phenylisopropyl methylamine hydrochloride (Orthoxine, Upjohn), of the class of ephedrine, was studied and appeared quite similar to the latter in protecting capacity. Brief clinical trial indicated that the ortho-methoxy group may occasionally reverse the central stimulation of ephedrine.

\section{ACKNOWLEDGMENT}

We are indebted to Dr. H. J. Rubitsky for carrying out several protection study tests in this series. 


\section{BIBLIOGRAPHY}

1. Goodman, L., and Gilman, A., The Pharmacological Basis of Therapeutics. The Macmillan Co., New York, 1941.

2. Barger, G., and Dale, H. H., Chemical structure and sympathomimetic action of amines. J. Physiol., 1910, 41, 19.

3. Gunn, J. A., The pharmacological actions and therapeutic uses of some compounds related to adrenaline. Brit. M. J., 1939, 2, 155.

4. Siegmund, O. H., Granger, H. R., and Lands, A. M., The bronchodilator action of compounds structurally related to epinephrine. J. Pharmacol. \& Exper. Therap., 1947, 90, 254.

5. Lands, A. M., Nash, V. L., McCarthy, H. M., Granger, H. R., and Dertinger, B. L., The pharmacology of N-alkyl homologues of epinephrine. J. Pharmacol. \& Exper. Therap., 1947, 90, 110.

6. Marsh, D. F., Pelletier, M. H., and Ross, C. A., The comparative pharmacology of the $\mathrm{N}$-alkylarterenols. J. Pharmacol. \& Exper. Therap., 1948, 92, 108.

7. Lands, A. M., Nash, V. L., Dertinger, B. L., Granger, H. R., and McCarthy, H. M., The pharmacology of compounds structurally related to hydroxytyramine. J. Pharmacol. \& Exper. Therap., 1948, 92, 369.

8. Segal, M. S., Beakey, J. F., Bresnick, E., and Levinson, L., Evaluation of therapeutic substances employed for the relief of bronchospasm. Bull. New England M. Center, 1948, 10, 21.

9. Levinson, L., Beakey, J. F., Bresnick, E., and Segal, M. S., Evaluation of therapeutic substances employed for the relief of bronchospasm. II. Historical development and methods. Ann. Allergy, 1948, 6, 705.
10. Graeser, J. B., and Rowe, A. H., Inhalation of epinephrine for the relief of asthmatic symptoms. J. Allergy, 1935, 6, 415.

11. Richards, D. W., Jr., Barach, A. L., and Cromwell, H. A., Use of vaporized bronchodilator solutions in asthma and emphysema. A continuous inhalation method for severe asthmatic states. Am. J. M. Sc., 1940, 199, 225.

12. Segal, M. S., Beakey, J. F., Bresnick, E., and Levinson, L., A comparison of various sympathomimetic amines in counteracting the dyspnea and bronchospasm induced by histamine and acetyl-beta-methylcholine. J. Allergy, 1949, 20, 97.

13. Graeser, J. B., Inhalation therapy of bronchial asthma. J. A. M. A., 1939, 112, 1223.

14. Barach, A. L., Physiological methods in the diagnosis and treatment of asthma and emphysema. Ann. Int. Med., 1938, 12, 454.

15. Burrage, W. S., Recent therapeutic trends in allergy. New England J. Med., 1948, 238, 181.

16a. Konzett, H., Neue broncholytisch hochwirksame Körper der Adrenalinreihe. Arch. f. exper. Path. u. Pharmakol., 1940, 197, 27.

b. Konzett, H., Zur Pharmakologie neuer adrenalinverwandter Körper. Ibid., 1940, 197, 41.

17. Segal, M. S., and Beakey, J. F., The use of isuprel for the management of bronchial asthma. Bull. New England M. Center, 1947, 9, 62.

18. Segal, M. S., and Beakey, J. F., Management of bronchial asthma; the use of $1-\left(3^{\prime}, 4^{\prime}\right.$-dihydroxyphenyl)-2-isopropylaminoethanol. Ann. Allergy, 1947, 5, 317.

19. Cohen, E. N., and Van Bergen, F., Isuprel, a new bronchodilating agent. Bull. Univ. of Minn. Hospitals \& Minn. Med. Foundation, 1948, 19, 424. 